\title{
Genetics of cold-adapted B/Ann Arbor/1/66 influenza virus reassortants: the acidic polymerase (PA) protein gene confers temperature sensitivity and attenuated virulence
}

\author{
Armen M. Donabedian, Dan C. DeBorde and Hunein F. Maassab* \\ 'Department of Epidemiology, The University of Michigan, 109 Observatory St, Ann Arbor. \\ Michigan 48109, U.S.A.
}

(Received February 9, 1987; accepted in revised form April 16, 1987)

Donabedian, A. M. (Dept of Epidemiology, The University of Michigan, 109 Observatory St, Ann Arbor, Michigan 48109, U.S.A.), D. C. DeBorde and H. F. Maassab. Genetics of coldadapted B/Ann Arbor/1/66 influenza virus reassortants: the acidic polymerase (PA) protein gene confers temperature sensitivity and attenuated virulence. Microbial Pathogenesis 1987; 3 : 97-108.

The cold-adapted B/Ann Arbor/1/66 influenza virus (ca B/AA/1/66) expresses temperaturesensitive (ts), cold-adapted (ca) and attenuation phenotypes. Reassortants which inherit one or more genes from ca $\mathrm{B} / \mathrm{AA} / 1 / 66$ and all other genes from a virulent, wild-type influenza virus, $B /$ Houston/1732/76, were produced and evaluated in order to identify the gene(s) responsible for the ts, ca and attenuation phenotypes. Only reassortants which inherited the PA gene from ca $\mathrm{B} / \mathrm{AA} / 1 / 66$ expressed the ts phenotype in MDCK cells at $39^{\circ} \mathrm{C}$. None of the reassortants tested expressed the ca phenotype in embryonated eggs at $25^{\circ} \mathrm{C}$. The virulence of several reassortants was evaluated in ferrets. Inheritance of the PA gene from ca $B / A A / 1 / 66$ was correlated with significant febrile attentuation and the apparent restriction of viral replication in the lower respiratory tract. Isolation of a virulent, non-ts revertant virus inheriting only the PA gene from ca $\mathrm{B} / \mathrm{AA} / 1 / 66$ established a direct relationship between expression of the ts phenotype and attenuated virulence. Evidence for the contribution of at least one other gene from ca B/AA/1/66 to attenuation was observed. Thus, based on the methods used to determine reassortant gene compositions, these results indicate that the PA gene is primarily responsible for attenuation of $\mathrm{ca} \mathrm{B} / \mathrm{AA} / 1 / 66$ and its reassortants.

Key words: Cold-adapted influenza B virus; vaccine; temperature-sensitive; acidic polymerase.

\section{Introduction}

The cold-adapted $B / A n n$ Arbor/1/66 influenza virus (ca $B / A A / 1 / 66$ ) has been developed for the production of live vaccines in a manner analogous to that of coldadapted $A / A n n$ Arbor/6/60 influenza virus (ca $A / A A / 1 / 66$ ). ${ }^{1-3}$ Preliminary studies indicate that vaccine candidate strains derived from ca $B / A A / 1 / 66$ are attenuated, genetically stable and antigenic in humans. ${ }^{4-6}$ Like its type $A$ counterpart, ca B/AA/1 /66 also expresses two temperature-dependent replication phenotypes in ovo and in vitro. These phenotypes are temperature sensitivity (ts), the restriction of viral replication at $39^{\circ} \mathrm{C}$; and cold adaptation (ca), the efficient replication of virus at $25^{\circ} \mathrm{C}$. The ts and ca

* To whom reprint requests should be addressed 
phenotypes of the ca $A / A A / 6 / 60$ virus have been associated with the attenuation of virulence in animals and man. ${ }^{7-11}$

The properties of temperature sensitivity, cold adaptation and attenuation can be transferred to reassortant progeny by the inheritance of RNA segments (genes) from ca $B / A A / 1 / 66$. The vaccine candidates produced in our laboratory are reassortants which inherit the six genes encoding the internal proteins from ca $B / A A / 1 / 66$ and the hemagglutinin (HA) and neuraminidase (NA) genes from a relevant wild-type virus. Although such candidates are attenuated, the particular segments of ca B/AA/1/66 which confer attenuation and the mechanisms by which attenuation is expressed are unknown. We have been interested in identifying the genes of ca $B / A A / 1 / 66$ that are responsible for attenuation in order to: (1) assess the value of the ts and ca phenotypes as laboratory markers of attenuation; (2) investigate the potential stability of attenuation; and (3) ultimately characterize attenuating lesions at the sequence level. For these purposes, a set of reasssortants inheriting one or more genes from ca $B / A A / 1 / 66$ and their remaining genes from a virulent, wild-type virus, $B /$ Houston/1732/76 (wt $B / H N / 1732 / 76$ ), were produced and evaluated for virulence in ferrets and for the expression of the ts and ca phenotypes.

\section{Results}

\section{The $P A$ gene of ca $B / A A / 1 / 66$ determines temperature sensitivity}

The derivation of reassortants inheriting only one gene from ca $B / A A / 1 / 66$ (single gene reassortants) was accomplished for all genes except the nucleoprotein (NP) gene. The ts properties of these reassortants in Madin-Darby canine kidney (MDCK) cells are shown in Table 1. As with the cold-adapted parent, reassortants that demonstrate no infectious titer at $39^{\circ} \mathrm{C}$ are temperature-sensitive (ts). Of the single ca gene reassortants tested, only the reassortant inheriting the PA gene (SG3*) from ca $\mathrm{B} / \mathrm{AA} / 1 / 66$ was temperature-sensitive at $39^{\circ} \mathrm{C}$ as demonstrated by the absence of a detectable infectious titer. The $\log _{10}$ reduction of infectious titers at $39^{\circ} \mathrm{C}$ as compared to $33^{\circ} \mathrm{C}$ of all other single gene reassortants were similar to that of wt $\mathrm{B} / \mathrm{HN} / 1732 / 76$.

The ts properties of reassortants inheriting more than one gene from ca $B / A A / 1 / 66$ (multiple gene reassortants) were also determined to investigate the expression of the ts phenotype by the combination of ca B/AA/1/66 genes. As before, the expression of the ts phenotype was consistently correlated with the inheritance of only the PA gene from ca $B / A A / 1 / 66$. Reassortants that failed to express the ts phenotype included a reassortant ( $M G 12478$ ) that inherited all internal protein genes from ca $B / A A / 1 / 66$ except the PA gene. Thus, the $P A$ gene of ca $B / A A / 1 / 66$ was responsible for the expression of temperature sensitivity.

Reassortants MG124678, MG12478 and MG1247 were somewhat more temperature-sensitive at $39^{\circ} \mathrm{C}$ than the wt parent was. These reassortants probably possess one or more 'leaky' ts mutations. In experiments using MG12478, plaque titration at $40^{\circ} \mathrm{C}$ or $41^{\circ} \mathrm{C}$ did not result in further restriction and plaques isolated at $39^{\circ} \mathrm{C} \mathrm{remained}$ partially temperature-sensitive (data not shown). Thus, partial temperature sensitivity was neither indicative of a ts mutation requiring higher temperatures for full expression nor was it attributable to genetic instability of the ts phenotype. A single gene reassortant inheriting the NP gene from ca $B / A A / 1 / 66$ was not isolated. However, comparison of MG1247 with MG127 indicated that while the inheritance of only the

\footnotetext{
${ }^{*}$ For convenience, reassortants are identified by an identification (ID) code which indicates the RNA segments inherited from ca B/AA/ $\uparrow / 66$. The two-letter prefixes $S G$ and $M G$ stand for single gene and multiple gene reassortant. For example, MG12478 refers to the reasssortant inheriting multiple genes from ca B/AA/1/66, namely, RNAs 1, 2, 4, 7 and 8 .
} 
Table 1 Relative infectious titers $(\mathrm{pfu} / \mathrm{ml})$ of reassortants at $33^{\circ} \mathrm{C}$ and $39^{\circ} \mathrm{C}^{a}$

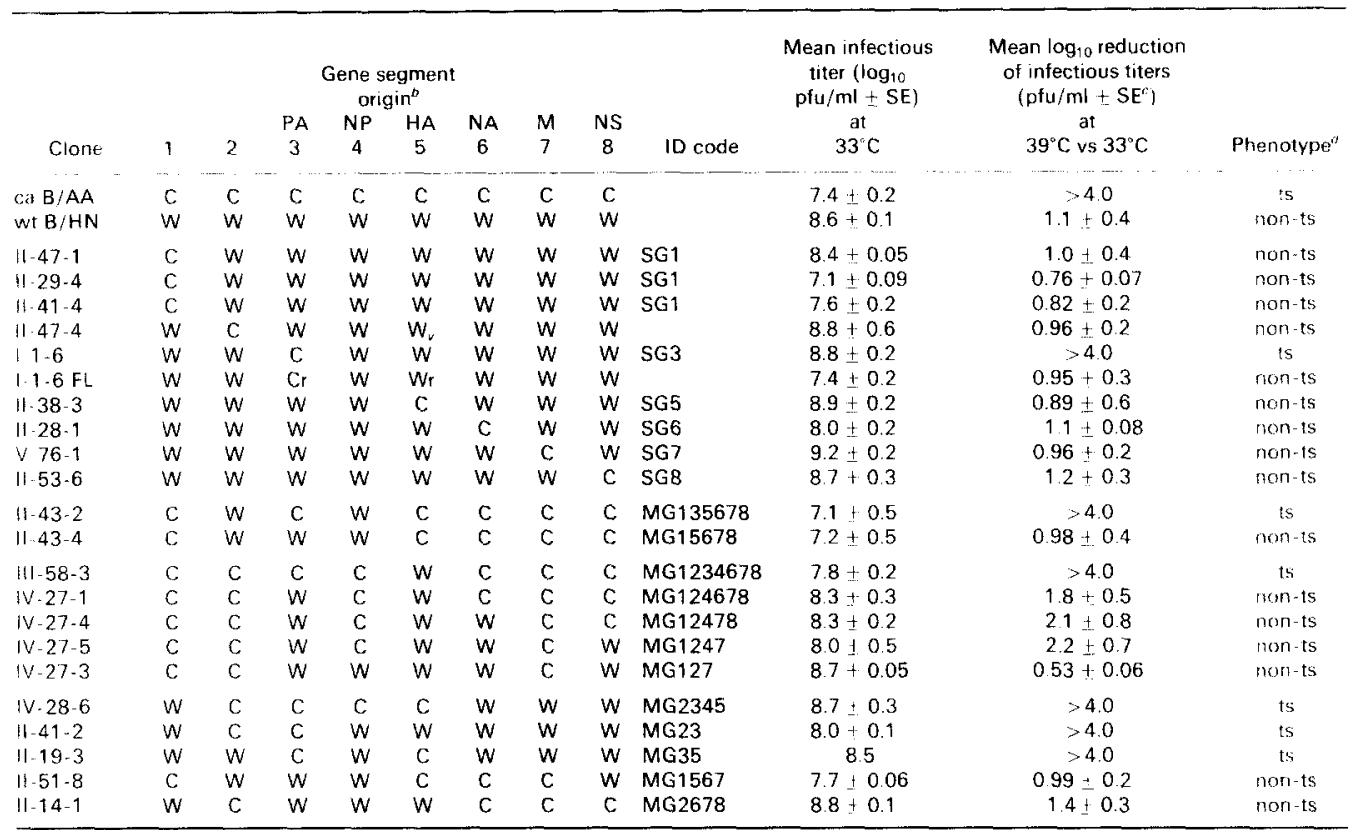

axcept for reassortant 1 -19-3, the values shown were determined from three or more experiments. SE - Standard error.

${ }^{b}$ Gene segment origin is indicated as follows-C: RNA segment is derived from ca B/AA/1/66; W: RNA segment is derived from wt $\mathrm{B} / \mathrm{HN} / 1732 / 76$; $\mathrm{W}_{v}$ : RNA segment matches the indicated parent but, the encoded protein varies from both parental strains; $\mathrm{Cr}$ and $\mathrm{Wr}$ : variant genes of ts-revertant virus isolated from ferret lungs. Gene coding assignments were determined as described in Materials and methods.

A $\log$ reduction of $>4.0$ indicates the absence of infectious titer at $39^{\circ} \mathrm{C}$. The titration of low dilution inocula resuits in the destruction of the cell monolayer without detectable plaque formation.

As with the cold-adapted parent, reassortants that demonstrate no infectious titer at $39^{\circ} \mathrm{C}$ are temperature-sensitive (ts)

NP gene from ca $B / A A / 1 / 66$ would not be sufficient for the expression of the ts phenotype, it could be associated with the expression of partial temperature sensitivity, either by itself, or in combination with the PB1, PB2 and/or M genes.

\section{Evaluation of the ca phenotype in eggs}

Replication of ca $\mathrm{B} / \mathrm{AA} / 1 / 66$ at $25^{\circ} \mathrm{C}$ in embryonated chicken eggs was clearly distinguished from that of wt $\mathrm{B} / \mathrm{HN} / 1732 / 76$ (Table 2) on the basis of the $\log _{10}$ reduction of infectious titers $\left(E I D_{50} / \mathrm{ml}\right)$ at $25^{\circ} \mathrm{C}$ as compared with $33^{\circ} \mathrm{C}$. Viruses that express the ca phenotype were defined as those demonstrating less than a $2 \log _{10}$ reduction of infectious titers at $25^{\circ} \mathrm{C}$ versus $33^{\circ} \mathrm{C}$, that is, they should replicate with roughly the same efficiency as the ca parent does. By this criteria, none of the reassortants tested expressed the ca phenotype. However, with respect to the wt parent, several reassortants demonstrated substantially improved replication at $25^{\circ} \mathrm{C}$ versus $33^{\circ} \mathrm{C}$ as indicated in Table 2 . Among the single gene reassortants, only the reassortant inheriting the $\mathrm{HA}$ gene from ca $\mathrm{B} / \mathrm{AA} / 1 / 66$ (SG5) demonstrated improved replication at $25^{\circ} \mathrm{C}$. Although a single gene reassortant inheriting the NP gene from ca $\mathrm{B} / \mathrm{AA} / 1 / 66$ was not isolated, such a reassortant would not be expected to express cold adaptation since MG124678, MG12478 and MG1247 failed to demonstrate even intermediate replication at $25^{\circ} \mathrm{C}$.

All multiple ca gene reassortants inheriting the $\mathrm{HA}$ gene from ca $\mathrm{B} / \mathrm{AA} / 1 / 66$ also demonstrated improved replication at $25^{\circ} \mathrm{C}$. However, evidence for contributions from other genes was observed since MG1234678 (inheriting only the HA gene from the wt parent) demonstrated intermediate replication and two multiple gene reassortants (MG135678 and MG2345), inheriting genes from the ca parent in addition to the HA 
Table 2 Evaluation of the ca phenotype in embryonated eggs

\begin{tabular}{|c|c|c|c|c|c|c|c|c|c|c|c|c|}
\hline \multirow[b]{2}{*}{ Clone } & \multirow[b]{2}{*}{1} & \multirow[b]{2}{*}{2} & \multicolumn{4}{|c|}{$\begin{array}{c}\text { Gene segment } \\
\text { origin }^{3}\end{array}$} & \multirow[b]{2}{*}{$\begin{array}{c}M \\
7\end{array}$} & \multirow[b]{2}{*}{$\begin{array}{c}\text { NS } \\
8\end{array}$} & \multirow[b]{2}{*}{ ID code } & \multirow{2}{*}{ 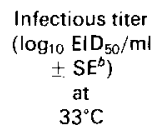 } & \multirow{2}{*}{$\begin{array}{c}\log _{10} \text { reduction } \\
\text { of infectious titers } \\
\left(\mathrm{EID}_{50} / \mathrm{ml} \pm \mathrm{SE}^{c)}\right. \\
\text { at } \\
25^{\circ} \mathrm{C} \text { vs } 33^{\circ} \mathrm{C}\end{array}$} & \multirow[b]{2}{*}{ Phenotype } \\
\hline & & & $\begin{array}{c}\mathrm{PA} \\
3\end{array}$ & $\begin{array}{c}\mathrm{NP} \\
4\end{array}$ & $\begin{array}{c}\text { HA } \\
5\end{array}$ & $\begin{array}{c}\text { NA } \\
6\end{array}$ & & & & & & \\
\hline $\begin{array}{l}\text { ca } B / A A \\
\text { wt } B / H N\end{array}$ & $\begin{array}{l}c \\
w\end{array}$ & $\begin{array}{l}c \\
W\end{array}$ & $c$ & $\begin{array}{l}\mathrm{C} \\
\mathrm{W}\end{array}$ & $\begin{array}{l}c \\
w\end{array}$ & $\begin{array}{l}C \\
W\end{array}$ & $\begin{array}{l}C \\
W\end{array}$ & $\stackrel{c}{W}$ & & $\begin{array}{l}7.7 \pm 0.3 \\
8.5 \pm 0.1\end{array}$ & $\begin{array}{l}0.9+0.4 \\
4.9 \pm 0.2\end{array}$ & $\begin{array}{c}\text { ca } \\
\text { non-ca }\end{array}$ \\
\hline $\mid 1-41-4$ & $\mathrm{C}$ & $w$ & w & w & $w$ & W & $w$ & w & SG1 & $9.5 \pm 0.0$ & $5.2 \pm 0.4$ & non-ca \\
\hline $11-47-4$ & $w$ & C & $w$ & w & $W_{v}$ & $w$ & $w$ & w & & $8.8 \pm 0.2$ & $>5.2$ & non-ca \\
\hline $1-1-6$ & $w$ & $w$ & C & w & $w$ & $w$ & $w$ & w & SG3 & $9.5 \pm 0.0$ & $5.5 \pm 0.3$ & non-ca \\
\hline $1-1.6 \mathrm{FL}$ & w & $w$ & $\mathrm{Cr}$ & $w$ & $w_{r}$ & $w$ & $w$ & $w$ & & $8.5 \pm 0.2$ & $4.5+0.4$ & non-ca \\
\hline $11-38-3$ & $w$ & $w$ & w & $w$ & $c$ & $w$ & w & $w$ & SG5 & $9.0+0.2$ & $3.6 \pm 0.3$ & int. \\
\hline $11-28-1$ & w & $w$ & w & w & w & C & $w$ & w & SG6 & $9.2 \pm 0.2$ & $5.2 \pm 0.4$ & non-ca \\
\hline$V-76-1$ & w & w & w & w & $w$ & $w$ & $c$ & w & SG7 & $8.5 \pm 0.0$ & $4.8+0.2$ & non-ca \\
\hline II-53-6 & w & $w$ & w & w & w & $w$ & $w$ & C & SG8 & $9.0 \pm 0.3$ & $4.8 \pm 0.4$ & non-ca \\
\hline $11-43-2$ & C & $w$ & $\mathrm{C}$ & w & $\mathrm{C}$ & c & $c$ & C & MG135678 & $6.9 \pm 0.2$ & $2.2 \pm 0.3$ & int. \\
\hline II- $43-4$ & C & w & w & w & C & $\mathrm{C}$ & C & $\mathrm{C}$ & MG15678 & $9.5 \pm 0.0$ & $3.5 \pm 0.2$ & int. \\
\hline III-58-3 & C & C & C & C & $w$ & $\mathrm{C}$ & $c$ & C & MG1234678 & $9.4 \pm 0.08$ & $3.9 \pm 0.2$ & int. \\
\hline IV $-27-1$ & C & $\mathrm{C}$ & $w$ & C & $w$ & C & C & C & MG124678 & $8.5 \pm 0.0$ & $4.8 \div 0.2$ & non-ca \\
\hline IV $-27-4$ & C & C & W & C & w & $w$ & $\mathrm{C}$ & C & MG12478 & $9.2+0.2$ & $4.8 \pm 0.4$ & non-ca \\
\hline IV-27-5 & $\mathrm{C}$ & $\mathrm{C}$ & w & C & w & $w$ & $\mathrm{C}$ & w & MG1247 & $8.5+0.0$ & $4.5 \pm 0.3$ & non-ca \\
\hline IV-27-3 & $\mathrm{C}$ & $\mathrm{C}$ & w & w & w & w & $\mathrm{C}$ & w & MG127 & $9.0 \pm 0.3$ & $5.0 \pm 0.4$ & non-ca \\
\hline IV-28-6 & w & C & $\mathrm{c}$ & C & $\mathrm{C}$ & $w$ & $w$ & w & MG2345 & $9.2 \pm 0.2$ & $2.3 \pm 0.4$ & int. \\
\hline $11-41-2$ & w & $\mathrm{C}$ & $\mathrm{C}$ & w & w & W & w & w & MG23 & $8.5 \pm 0.4$ & $4.8 \pm 0.4$ & non-ca \\
\hline II-19-3 & w & $w$ & $\mathrm{C}$ & w & $\mathrm{C}$ & w & $w$ & w & MG35 & $8.9 \pm 0.2$ & $3.3 \pm 0.3$ & int. \\
\hline $11-51-8$ & $\mathrm{C}$ & $w$ & W & w & $\mathrm{C}$ & $\mathrm{C}$ & $\mathrm{C}$ & w & MG1567 & $9.4 \pm 0.1$ & $3.5 \pm 0.4$ & int. \\
\hline $\mid 1-14-1$ & $w$ & C & W & w & $w$ & c & $\mathrm{C}$ & c & MG2678 & $8.2 \pm 0.2$ & $4.5+0.4$ & non-ca \\
\hline
\end{tabular}

'Gene segment origin is indicated as follows - $C$ : RNA segment is derived from ca B/AA/1/66: W: RNA segment is derived from wt $\mathrm{B} / \mathrm{HN} / 1732 / 76: \mathrm{W}_{v}$ : RNA segment matches the indicated parent but the encoded protein varies from both parental strains: $\mathrm{Cr}$ and $\mathrm{Wr}$ : variant genes of the ts-revertant virus isolated from ferret lungs. Gene coding assignments were determined as described in Materials and methods.

${ }^{b} \mathrm{SE}=$ standard error.

'As with the cold-adapted parent, reassortants that demonstrate less than a $2 \log$, $_{0}$ reduction of infectious titers at $25^{\circ} \mathrm{C}$ vs $33^{\circ} \mathrm{C}$ are coldadapted (ca). Reassortants demonstrating improved replication at $25^{\circ} \mathrm{C}$ vs $33^{\circ} \mathrm{C}$ in comparison to the witd-type parent are intermediate (int.).

gene, demonstrated further improvement with respect to SG5. Comparison of MG15678 with MG135678, as well as MG124678 with MG1234678, indicated that the PA gene of ca B/AA/1/66 increased the degree of cold adaptation in certain multiple gene reassortants. Interestingly, the inheritance of only the HA and PA genes from the wt parent was sufficient to abrogate cold adaptation in MG124678 but, inheritance of only these genes from the ca parent was not sufficient to confer the ca phenotype on MG35.

\section{Evaluation of virulence}

In order to determine the relative contributions of $\mathrm{ca} B / \mathrm{AA} / 1 / 66$ genes to attenuation, a limited number of reassortants were assayed for virulence in ferrets (Table 3 ). Virulence was evaluated on the basis of fever and viral replication in the upper respiratory (nasal turbinates) and lower respiratory (lungs) tracts. The virulence of ca $B / A A / 1 / 66$ was clearly distinguished from that of wt $B / H N / 1732 / 76$ using the ferret model system. The wt parent produced fever in all ferrets, replicated well in the turbinates, and was isolated from the lungs of 4 of 12 infected ferrets. In contrast, the ca parent produced fever in only 1 of 6 ferrets, replicated poorly in the turbinates and was not isolated from the lungs.

Significant febrile attenuation was expressed only by the two reassortants (SG3 and MG23) inheriting the PA gene from ca $B / A A / 1 / 66$. Like the ca parent, the mean peak temperature of ferrets infected with either reassortant was significantly less than that of the wt virus. Although the precise level of febrile attenuation attributable to the inheritance of the PA gene was variable, these results indicated that the PA gene of ca $\mathrm{B} / \mathrm{AA} / 1 / 66$ was a major contributor to the attenuation of virulence. This observation was corroborated by the febrile response to MG12478, which induced a 
Table 3 Febrile response and viral replication in ferrets

\begin{tabular}{|c|c|c|c|c|c|c|c|}
\hline Clone & ID code & $\begin{array}{l}\text { Mean peak } \\
\text { Temp } \pm S E^{j}\end{array}$ & $\begin{array}{l}\text { No. of ferrets } \\
\text { with fever } \\
\geqslant 103.4 / \\
\text { No. infected }\end{array}$ & \multicolumn{2}{|c|}{$\begin{array}{l}\text { Lung }^{b} \\
\text { No. positive/ } \\
\text { No. infected }\end{array}$} & \multicolumn{2}{|c|}{$\begin{array}{c}\text { Turbinate } \\
\text { mean } \\
\log _{10} \mathrm{pfu} / \mathrm{ml} \pm \mathrm{SE}\end{array}$} \\
\hline ca B/AA/1/66 & & $103.1 \pm 0.6^{*}$ & $1 / 6$ & $0 / 3$ & $0 / 3$ & $3.7 \pm 0.5$ & $2.9 \pm 0.2$ \\
\hline $1-1-6$ & SG3 & $102.6 \pm 0.9^{*}$ & $1 / 6$ & $1 / 3$ & $0 / 3$ & $5.4 \pm 0.3$ & $4.6+0.6$ \\
\hline $\mid 1-41-2$ & MG23 & $103.3 \pm 0.6^{*}$ & $3 / 6$ & $0 / 3$ & $0 / 3$ & $6.0 \pm 0.2$ & $5.5 \div 0.2$ \\
\hline IV $-27-4$ & MG 12478 & $103.6 \pm 0.6$ & $9 / 12$ & $0 / 6$ & $0 / 6$ & $6.1 \pm 0.4$ & $5.0 \pm 0.1$ \\
\hline$V-76-1$ & SG7 & $103.7 \pm 0.4$ & $10 / 12$ & $1 / 6$ & $2 / 6$ & $6.5 \pm 0.2$ & $6.1+0.4$ \\
\hline $1-1-6 \mathrm{FL}$ & & $103.9 \pm 0.2$ & $6 / 6$ & $1 / 3$ & $1 / 3$ & $6.9 \pm 0.3$ & $6.0+0.4$ \\
\hline $\mid 1-41-4$ & SG1 & $103.8 \pm 0.2$ & $6 / 6$ & $1 / 3$ & $2 / 3$ & $7.0 \pm 0.3$ & $6.2 \div 0.2$ \\
\hline wt B/HN/1732/76 & & $103.8 \pm 0.2$ & $12 / 12$ & $2 / 6$ & $2 / 6$ & $6.1 \pm 0.3$ & $5.4: 0.1$ \\
\hline
\end{tabular}

$a$ * = mean differs significantly $(P<0.05)$ from $w t \mathrm{~B} / \mathrm{HN} / 1732 / 76$ by Student's $t$-test. SE $=$ standard error.

${ }^{b}$ Values determined from $10 \%$ lung and turbinate suspensions.

mean peak temperature significantly higher than those induced by the ca parent and SG3. This result also suggested that the PA gene from ca $B / A A / 1 / 66$ may be essential for the maximum attenuation of a vaccine candidate strain produced with ca $B / A A / 1 / 66$.

With the exception of one ferret (see below), SG3 and MG23 were not recovered from the lungs of infected animals, tentatively indicating a role for the PA gene in the restriction of viral replication in the lower respiratory tract. The apparent restriction of replication observed for MG12478 in the lungs of infected ferrets suggested that at least one, as yet unidentified, gene other than the PA gene from ca B/AA/1/66 was also involved in attenuation. By themselves, RNA 1 and the matrix (M) gene were excluded as potential contributors, since SG1 and SG7 demonstrated virulence comparable to that of wt B/HN/1732/76.

The level of viral replication in ferret turbinates was determined at 2 and 4 days after infection (Table 3). All viruses grew well in the turbinates except ca B/AA/1/66. It could not be determined which genes of the ca parent were responsible for this character. Fever was frequently observed in groups of ferrets demonstrating mean virus titers in turbinates at day 2 of $6.0 \log _{10} \mathrm{pfu} / \mathrm{ml}$ or greater. The mean turbinate titer at day 2 of ferrets demonstrating fever was $6.5 \pm 0.5 \log _{10} \mathrm{pfu} / \mathrm{ml}$. The mean turbinate titer at day 2 of ferrets not demonstrating fever was $5.2 \pm 1.1 \log _{10} \mathrm{pfu} / \mathrm{ml}$. These two samples yield a $t$-statistic of $4.5\left(P=1.0 \times 10^{4}\right.$ at 31 d.f. $)$, suggesting a relationship between viral replication in ferret turbinates and the presence or absence of fever.

A weaker, but still significant, relationship was also observed between the occurrence of fever at any time and mean virus titer in the turbinates at day 4 . However, this relationship was not correlated with late occurring or enduring fevers and probably reflects the stronger relationship found to occur earlier in infection. The apparent rate at which virus titers in the turbinates fell between days 2 and 4 differed among the viruses assayed. No relationship between the reduction of turbinate titer with segment composition or fever could be inferred from the data. 
expected to replicate at what should be the restrictive temperature of the ferret lower respiratory tract. ${ }^{12}$ As a result, it was of interest to determine if this virus had undergone modification of its ts phenotype. Plaque titration at $39^{\circ} \mathrm{C}$ revealed a virus subpopulation, designated I-1-6 FL, which had lost temperature sensitivity (Table 1). When administered to ferrets, I-1-6 FL produced fevers comparable to and was recovered from the lungs at the same frequency as the wt parent (Table 3 ). Thus, loss of the ts phenotype by SG3 was accompanied by a corresponding reversion to virulence. Since the PA gene of ca $B / A A / 1 / 66$ was previously shown to be responsible for its ts phenotype, this result established a direct relationship between attenuation and the expression of the ts phenotype by ca B/AA/1/66.

In order to investigate the genetic changes that may have occurred in the ts-revertant 1-1-6 FL, the migration of 1-1-6 FL and SG3 RNA segments were compared at different temperatures on mixed polyacrylamide-agarose gels (Fig. 1). Only the PA and HA genes of 1-1-6 FL demonstrated altered migration. Altered migration was clearly observed at $26^{\circ} \mathrm{C}$ for the PA gene and at $34^{\circ} \mathrm{C}$ for the $\mathrm{HA}$ gene. Comparison of I-1-6 FL and SG3 proteins on 5-13\% SDS-polyacrylamide gels did not reveal any differences in migration (not shown). In addition, the HA proteins of wt B/HN/1732/76, I-1-6 $\mathrm{FL}$, and SG3 were antigenically indistinguishable by hemagglutination inhibition. These results suggested that small changes in the PA and possibly HA genes of SG3 have resulted in its loss of the ts phenotype and attenuation. However, a more rigorous determination of the presence or absence of extragenic suppressor mutations is required.

\section{Discussion}

Cold-adapted $\mathrm{B} / \mathrm{AA} / 1 / 66$ was developed as a donor of attenuating genes for the production of live influenza virus vaccines. In addition to attenuation, ca B/AA/1/66 expresses the ts and ca phenotypes. Allied with electrophoretic characterization of the segmented influenza virus genome, the ts and ca phenotypes are routinely used as in vitro markers to identify vaccine candidate strains without specific knowledge of their association with attenuation. ${ }^{4,5,13}$ Through genetic reassortment, one or more genes of ca $B / A A / 1 / 66$ can be segregated among reassortant progeny that inherit their remaining genes from a virulent wild-type virus. Based on our determination of reassortant gene compositions, the contributions of several genes to temperature sensitivity, cold adaptation and the attenuation of virulence were described.

The data showed that inheritance of the PA gene from ca B/AA/1/66 was responsible for the transfer of the ts phenotype to wt $B / H N / 1732 / 76$. The possibility that spontaneous mutations may influence or be responsible for the expression of the ts phenotype, rather than the inheritance of genes from ca $B / A A / 1 / 66$, is discounted by the consistent expression of the ts phenotype only by multiple gene reassortants inheriting the PA gene from the ca parent. For example, it is unlikely that the variant HA protein of reassortant $1 \mathrm{I}-47-4$ (inheriting only RNA 2 from ca B/AA/1/66) suppresses temperature sensitivity in this reassortant since inheritance of RNA 2 from the ca parent is unassociated with the ts phenotype in multiple gene reassortants. Similar reasoning discounts the influence of potentially undetected mutations in reassortant II-47-4 and, by comparing the appropriate reassortants, in the other single gene reassortants as well.

Inheritance of the PA gene from ca $B / A A / 1 / 66$ was also found to correlate with significant attenuation of virulence. Furthermore, evaluation of a virulent, non-ts revertant reassortant $(1-1-6 \mathrm{FL})$ demonstrated that attenuation conferred by the inheritance of the PA gene from ca $B / A A / 1 / 66$ was mediated by the expression of its 


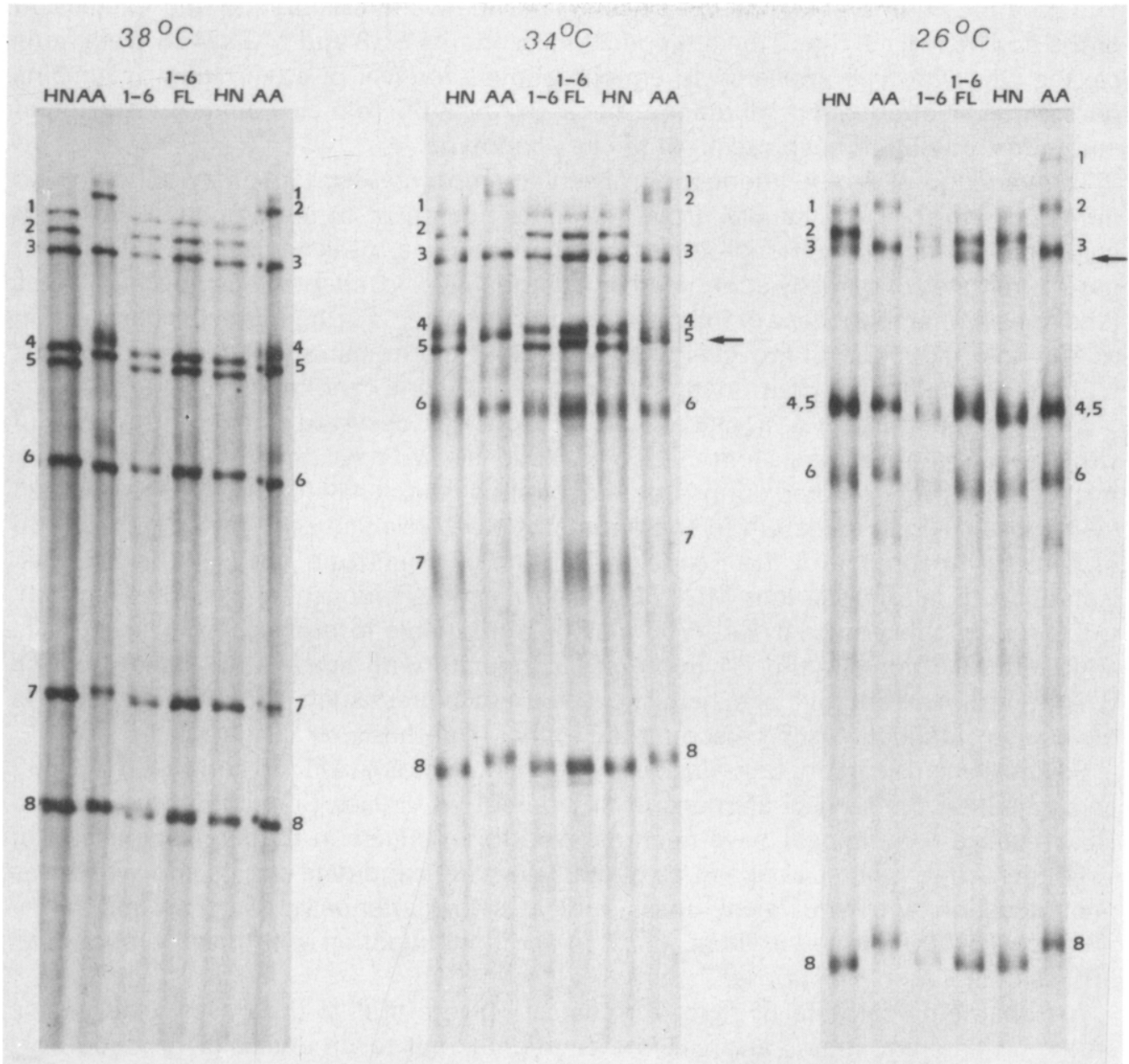

Fig. 1. Genetic variation in the ts-revertant I-1-6 FL. ${ }^{3}[\mathrm{H}]$ uridine-labeled vRNA was subjected to electrophoresis in mixed agarose-polyacrylamide gels at $38^{\circ} \mathrm{C}, 34^{\circ} \mathrm{C}$, and $26^{\circ} \mathrm{C}$. Arrows indicate variant segments in 1-1-6 FL. HN: wt B/HN/1732/76. AA: ca B/AA/1/66: reassortant I-1-6 (SG3). 1-6 FL: ts-revertant I-1-6 FL.

ts phenotype. As a result, the ts phenotype should be considered an important laboratory marker of attenuated virulence for the ferret animal model.

In contrast to the ts phenotype, the ca phenotype could not be associated with a single gene. Efficient growth at $25^{\circ} \mathrm{C}$ apparently involved several mutations, some of which required the interaction of genes for expression. We hypothesize that the transfer of wt genes to an otherwise ca virus may disable replication at $25^{\circ} \mathrm{C}$ in the same sense that the inheritance of genes bearing ts lesions disable replication at elevated temperatures. Alternatively, the apparent contributions of the PA and HA genes of ca $B / A A / 1 / 66$ may suggest that these genes act cooperatively with other genes to effect the expression of the ca phenotype. The complexity of such an interaction is indicated by comparison of reassortants MG135678 and MG2345 (i.e. several genes would be involved). In either case, among reassortants produced with wt $\mathrm{B} / \mathrm{HN} / 1732 / 76$, the minimum number of genes from the ca parent sufficient for the expression of the ca phenotype equivalent to ca B/AA/1/66 in ovo would include the HA and PA genes. 
The data provide no evidence for a relationship between attenuation and expression of the ca phenotype. Since the attenuated reassortants SG3 and MG12478 were non$\mathrm{ca}$, the ca phenotype appeared to emerge above the level of attenuation. It remains possible that attenuating mutations in ca $B / A A / 1 / 66$ form a necessary subset of mutations required for expression of the ca phenotype.

The variation of febrile attenuation observed among reassortants may be related to differences in their replication in the turbinates compared to the ca parent. For both cold-adapted and conditional-lethal ts mutant viruses, peak virus titers in hamster nasal turbinates of partially attenuated or reactogenic cold-adapted vaccine candidates tend to be higher than those of fully attenuated viruses. ${ }^{14.15}$ Furthermore, the observation of 100 -fold reduction in the level of replication in the human nasopharynx correlates with the attenuation of cold-adapted influenza A vaccine candidates. ${ }^{11}$.

In the present study, a significant association was observed between the level of virus titers in the turbinates and the febrile response two days after infection. A similar relationship is encountered during influenza $A$ virus infection of ferrets. ${ }^{16-18}$ Pronounced restriction of viral replication in the turbinates was observed only for ca $B / A A / 1 / 66$ (Table 3). Inheritance of the PA gene from the ca parent did not result in a similar restriction. Since reassortant MG12478 also did not demonstrate restricted growth, the low virus titers of ca $B / A A / 1 / 66$ may be attributable to one or both of its surface antigens. Alternatively, the PA gene may cooperate with some other gene(s) of ca $\mathrm{B} / \mathrm{AA} / 1 / 66$ in an additive or synergistic fashion to express such restriction. The results of vaccine candidate testing discount the former hypothesis.

Several vaccine candidate strains derived from both $\mathrm{ca} B / A A / 1 / 66$ and ca $A / A A / 6 / 60$ and inheriting the surface antigens from different wt viruses (including both $\mathrm{H} 1$ and $\mathrm{H} 3$ influenza $\mathrm{A}$ subtypes) have been assayed for virulence in ferrets. Comparison of virus titers in turbinates between ca parents, vaccine candidate strains and wt viruses after infection with equivalent doses, indicates that attenuated viruses consistently produce 10-100 fold lower titers. ${ }^{3-5,13,19}$ In addition, infection with these viruses does not result in a febrile response.

Histopathological data of ferret turbinates indicate that at the doses used in this study, ca parental strains and vaccine candidates fail to prodcuce or produce only mild histopathology in ferret nasal turbinates. ${ }^{4,5.13,19}$ In contrast, infection with wt viruses always produces severe histopathology. Thus, cold-adapted viruses grow to lower titers in nasal turbinates and fail to induce an inflammatory response comparable to $w t$ viruses. Since fever coincides with the inflammatory response and inflammation is essentially a response to tissue injury, ${ }^{20}$ the restricted replication of ca $B / A A / 1 / 66$ in the URT appeared to be an important determinant of attenuated virulence.

Genetically stable attenuation is a necessary component of a suitable vaccine donor strain. Since mutation is essentially a random event, it is impossible to ensure genetic stability. However, the probability that mutation will result in a reversion to virulence is greatly diminished by the accumulation of attenuating lesions. Evidence for the involvement of at least two genes (PA and one or more genes of MG12478) in the attenuation of ca $B / A A / 1 / 66$ was observed. Thus, the stability of attenuation observed during limited trials of vaccine candidates produced with ca B/AA/1/66 would be expected.$^{4-6}$ Unfortunately, conditional-lethal ts donor strains possessing two attenuating lesions have been found to revert in children. ${ }^{21}$ As a result, to be reasonably confident that attenuation conferred by ca $B / A A / 1 / 66$ is acceptably stable for use as a live vaccine, it will be necessary to demonstrate additional attenuating lesions.

Finally, attenuation equivalent to ca $B / A A / 1 / 66$ could not be attributed to any of the reassortants tested. A recent analysis of single gene reassortants derived from ca A/AA/6/60 (performed in collaboration with M. H. Synder, NIAID, Bethesda, MD) 
has also failed to attribute complete attenuation to the inheritance of single genes $(\mathrm{H}$. F. Maassab, personnal communication). The full understanding of the attenuated virulence expressed by cold-adapted influenza viruses will require further investigation of cumulative or synergistic effects that may result from the interaction of ca B/AA/1/66 genes.

\section{Materials and methods}

Viruses and cel/s. The derivation of ca $\mathrm{B} / \mathrm{AA} / 1 / 66$ from an epidemic strain of type $\mathrm{B}$ influenza was described by Maassab and DeBorde. ${ }^{3}$ Wild-type $B / H N / 1732 / 76$ was obtained from $\mathrm{Dr}$ Robert Couch, Baylor University, Houston, TX. Prior to reassortment, the wt virus was cloned by two successive plaque isolations in MDCK cells.

The preparation, maintenance and infection of MDCK cells (Flow Laboratories, Rockville, MD) and primary chick kidney (PCK) cells were described previously. ${ }^{722.23}$ Except where otherwise stated, all media used to propagate virus in MDCK cells contained $1 \mu \mathrm{g} / \mathrm{ml} \mathrm{L}$ (tosylamido-2-phenyl)ethyl chloroethyl ketone (TPCK) trypsin (Worthington Biochemicals, Bedford, MA).

Production of reassortants. Reassortants were produced by mating ca $\mathrm{B} / \mathrm{AA} / 1 / 66$ and wt $\mathrm{B} / \mathrm{HN} / 1732 / 76$ using a modification of the infectious center technique of Nakajima and Sugiura. ${ }^{24}$ PCK or MDCK cells were dually infected with $1-10 \mathrm{pfu} / \mathrm{ml}$ of each parental strain. After 1 hour of adsorption at room temperature, the cells were washed once with $\mathrm{Ca}^{2}$ and $\mathrm{Mg}^{2+}$ deficient HBSS and dispersed by treatment with $\mathrm{Ca}^{2+}$ and $\mathrm{Mg}^{2+}$ deficient $\mathrm{HBSS}$ containing $0.5 \%$ trypsin and $2 \%$ EDTA for 1 minute at room temperature. This solution was removed and incubation was continued for $3-5$ minutes at $35^{\circ} \mathrm{C}$. The dispersed cells were suspended in $10 \mathrm{ml}$ of HBSS and pelleted at $1000 \mathrm{~g}$ for 10 minutes. The cell pellet was resuspended and diluted so that the appropriate cell monolayer, grown in a $25 \mathrm{~cm}^{2}$ tissue culture vessel, was seeded with approximately 10,100 , or 500 infected cells. The cells were allowed to settle for 5 minutes and $5 \mathrm{ml}$ of overlay media was added. The overlay media used for PCK cells was composed of Medium 1, ${ }^{25} 0.8 \%$ agar (BBL Microbiology Systems, Cockeysville, MD), and 0.01\% DEAE-dextran (Pharmacia, Uppsala, Sweden). The overlay media used for MDCK cells was composed of Medium 199, $0.8 \%$ agarose (FMC, Rockville, $\mathrm{ME}$ ) and $5 \mu \mathrm{g} / \mu \mathrm{l}$ TPCK trypsin. After 2 days of incubation at $33^{\circ} \mathrm{C}$, the cell monolayers were stained by the addition of $4 \mathrm{ml}$ of the appropriate overlay media containing $0.01 \%$ neutral red. Individual plaques were picked on the third or fourth day after plating, suspended in $1 \mathrm{ml}$ of $\mathrm{E}$ MEM, diluted 10 -fold and replated as described above. The virus from individual plaques was replated to isolate pure reassortant clones. The virus isolated from individual plaques in the second plating was amplified at $33^{\circ} \mathrm{C}$ in eggs and gene compositions were determined by polyacrylamide gel electrophoresis of viral RNA (VRNA). Isolates identified as reassortants were purified by one plaque to plaque purification in MDCK cells at $33^{\circ} \mathrm{C}$ and amplified in eggs. The gene compositions of reassortants were verified after plaque purification.

Preparation of $\left[{ }^{3} \mathrm{H}\right]$ uridine-labeled vRNA. $\left[{ }^{3} \mathrm{H}\right]$ uridine-labeled vRNA was prepared from viruses grown in PCK cells. Confluent PCK cells grown in two $25 \mathrm{~cm}^{2}$ tissue culture vessels were infected and each incubated in the presence of $250 \mu \mathrm{Ci}$ of $\left[5-, 6-{ }^{3} \mathrm{H}\right]$ uridine $(35-50$ $\mathrm{Ci} / \mathrm{mmole}$, Amersham, Arlington Heights, IL) in $1.5 \mathrm{ml}$ of $2 \times$ Eagle's medium at $33^{\circ} \mathrm{C}$. After 4 hours $3 \mathrm{ml}$ of fresh $2 \times$ Eagle's medium was added and incubation was continued for 2 days.

Infected tissue culture media was clarified and the virus pelleted through a $30 \%$ sucrose cushion in STE buffer $(0.1 \mathrm{M}$ Tris- $\mathrm{HCl}, 0.001 \mathrm{M}$ EDTA, $\mathrm{pH} 7.4)$ as described previously. ${ }^{23}$ Viral RNA was phenol-chloroform extracted and resuspended in RNA loading buffer. ${ }^{23}$

Polyacrylamide ge/ electrophoresis of $v R N A$. The parental origins of reassortant RNA segments were routinely determined by polyacrylamide gel electrophoresis of vRNA at $38^{\circ} \mathrm{C}$ and $30^{\circ} \mathrm{C}$. The differences in migration between ca $B / A A / 1 / 66$ and wt $B / H N / 1732 / 76$ RNA segments (particularly for RNA segment 3 ) were small, but consistently reproducible using this method. In addition, the inheritance of the SG3 and I-1-6 FL PA genes from ca B/AA/1/66 was verified by sequence analysis (data not shown).

Polyacrylamide gel electrophoresis was performed using mixed agarose-polyacrylamide gels as described by Odagiri et al. ${ }^{22}$ Temperature control was accomplished by submerging the gels 
in running buffer $(1 \times$ TBE and $0.1 \%$ SDS) in an apparatus which was equilibrated in a heated 25 gallon fish tank. RNA samples were electrophoresed for 20 hours at a constant voltage of $240 \mathrm{~V}$. The gels were dryed and fluorographed as described previously. ${ }^{22}$

Coding assignments of RNA segments 3-8. The coding assignments of ca B/AA/1/66 and wt $B / H N / 1732 / 76$ RNA segments 3-8 were determined by (1) observing corresponding inheritance of RNA segments and proteins; and (2) by electroblot transfer of electrophoresed vRNA followed by hybridization with cDNA synthesized using primers specific for RNA segments $4-8$ of the $B /$ Lee/40 influenza virus.

The mapping strategy of corresponding inheritance was described by Racaniello and Palese ${ }^{26}$ and performed using standard techniques for protein electrophoresis. ${ }^{27,28}$ During this analysis, reassortant II-47-4 was observed to possess a variant $\mathrm{HA}$ protein as demonstrated by the altered migration of its HA2 subunit (not shown). This variant arose during reassortment or during initial amplification of the plaque isolate, presumably as the result of random mutation(s). We have indicated this gene to be inherited from wt $\mathrm{B} / \mathrm{HN} / 1732 / 76$ since reassortant $11-47-4$ was antigenically indistinguishable by hemagglutination inhibition.

The hybridization strategy was described by Dahlberg and Stellwag ${ }^{29}$ and exploited previously established coding assignments ${ }^{26}$ and sequence data ${ }^{30-34}$ for $\mathrm{B} / \mathrm{Lee} / 40$ influenza virus RNA segments. Primers were obtained from Dr Clayton Naeve, St Jude Children's Research Hospital, Memphis, TN. Complementary DNA was synthesized and labeled with $\left[{ }^{32} \mathrm{P}\right]-\mathrm{dATP}(1000-1500$ $\mathrm{Ci} / \mathrm{mmole}, \mathrm{NEN}$ ) in a double-volume ' $\mathrm{A}$ ' sequencing reaction as described by DeBorde et al. ${ }^{35}$ with the dideoxy-ATP being excluded. RNA segments 3-8 were found to respectively encode the PA, NP, HA, M and non-structural (NS) proteins ${ }^{36}$ (and unpublished data) as indicated in Tables 1 and 2. The basic polymerase proteins, PB1 and PB2, were not assigned.

Virus infectivity titration by plaque assay. Plaque assays were performed essentially as described previously. ${ }^{37,38}$ Monolayers of MDCK cells grown in 6- or 24-well plates were infected with 10 -fold serial dilutions of virus. Each dilution was infected into four replicate wells. The inoculum was removed and the cells were overlayed with plaquing media composed of $1 \times L$. 15 media, $0.002 \%$ phenol red, $0.8 \%$ agarose and $5 \mu \mathrm{g} / \mathrm{ml}$ TPCK trypsin. Infected cultures were incubated in parallel at $33^{\circ} \mathrm{C}$ and $39^{\circ} \mathrm{C}$ for 4 days. On the second day after infection, a second overlay of plaquing medium containing $0.01 \%$ neutral red was added.

Virus infectivity titration in embryonated eggs. Ten- or eleven-day-old embryonated eggs were inoculated allantoically through a side-puncture with $0.1 \mathrm{ml}$ of 10 -fold serially diluted virus. Each dilution was inoculated into 4 or more eggs. The puncture was sealed with paraffin and the eggs were incubated in parallel at $25^{\circ} \mathrm{C}$ for 5 days and at $33^{\circ} \mathrm{C}$ for 3 days. Approximately $1 \mathrm{ml}$ of allantoic fluid was harvested from each egg and the presence of virus was determined by hemagglutination of $0.5 \%$ chicken red blood cells. A $50 \%$ egg infectious dose $\left(E D_{50}\right)$ was calculated for each virus at $25^{\circ} \mathrm{C}$ and $33^{\circ} \mathrm{C}$ using the Spearman-Karber method. ${ }^{39}$

Virulence assays in ferrets. Neutered, male ferrets vaccinated against canine distemper (Marshall Research Farms, North Rose, NY) were used when 8-12 weeks old. Before infection, one third of the ferrets were screened for serum antibody against ca B/AA/1/66 and wt $\mathrm{B} / \mathrm{HN} / 1732 / 76$ by hemagglutinin inhibition. ${ }^{40}$ All ferrets tested demonstrated titers of less than $1: 2$.

Virus was administered intranasally to six ferrets at a dose of $6.5 \log _{10}$ pfu (MDCK, $33^{\circ} \mathrm{C}$ ) in $1 \mathrm{ml}$. Three ferrets were sacrificed at 2 and 4 days after infection. The nasal turbinates and a portion of the lower right lobe of the lung were excised and prepared as $10 \%$ tissue suspensions in E-MEM medium as described previously. ${ }^{4}$ The infectious titers of lung and turbinate suspensions were determined by plaque assay in MDCK sells at $33^{\circ} \mathrm{C}$. Rectal temperatures were taken twice daily.

We thank Curt W. Smitka, Suzanne Powell and George Anderson for expert technical assistance. This investigation was performed in partial fulfillment of the requirements for a Ph.D. degree in hospital and molecular epidemiology at the School of Public Health of The University of Michigan. Support was provided by the National Institute of Allergy and Infectious Diseases, NIH Contracts NOI-Al-72521 and NOI-AI-52564. A.M.D. is a recipient of the Eugene Payne Memorial Fellowship. 


\section{References}

1. Maassab HF. Adaptation and growth characteristics of influenza virus at $25^{\circ} \mathrm{C}$. Nature $1967 ; 213: 612$ 4.

2. Maassab HF, Kendal AP, Davenport FM. Hybrid formation of influenza virus at $25^{\circ} \mathrm{C}$. Proc Soc Exp Biol Med 1972; 139: 768-73.

3. Maassab HF, DeBorde DC. Development and characterization of cold-adapted viruses for use as live virus vaccines. Vaccine $1985 ; 3: 355-69$.

4. Davenport FM, Hennessey AV, Maassab HF, Minuse E, Clark LC, Abrams GD, Mitchell JR. Pilot studies on recombinant cold-adapted live type $A$ and $B$ influenza virus vaccines. $J$ Infect $D$ is $1977 ; 136: 17$ 25.

5. Monto AS, Miller FD, Maassab HF. Evaluation of an attenuated, cold-recombinant influenza $B$ virus vaccine. J Infect Dis 1982; 145: 57-64.

6. Reeve P, Pibermann M, Bachmayer H, Liehl E, Moritz A, Ganzinger U. Hofmann H, Kunz C. Studies in man with a cold-recombinant live influenza $B$ virus vaccine. Med Virol 1982; $91: 1-9$.

7. Maassab HF. Immunologic characteristics of cold-adapted influenza virus. J Immunol 1969; $102: 728$ 32.

8. Maassab HF, Monto AS, DeBorde DC, Cox NJ, Kendal AP. Development of cold recombinants of influenza virus as live virus vaccines. In: Nayak DP, ed. Genetic Variation Among Influenza Viruses. New York: Academic Press, 1981; 617-37.

9. Spring SB, Maassab HF, Kendal AP, Murphy BR, Chanock RM. Cold-adapted variants of influenza A II. Comparison of the genetic and biological properties of ts mutants and recombinants of the coldadapted A/AA/6/60 strain. Arch Virol 1977; 55: 233-46.

10. Odagiri T, Smitka CW, Maassab HF. Cold-adapted reassortants of influenza A virus in MDCK cells II. Role of the temperature-sensitive property of cold-adapted reassortants in mice. Microbiol Immunol 1983; 27: 203-6.

11. Snyder MH, Clements ML, DeBorde DC, Maassab HF, Murphy BR. Attenuation of wild-type human influenza $A$ virus by acquisition of the PA polymerase and matrix protein genes of influenza $A / A n n$ Arbor/6/60 cold-adapted donor virus. J Clin Microbiol 1985; 22: $719-25$.

12. Richman DD, Murphy BR, Chanock Rm. Demonstration of a non-temperature-sensitive growthrestricting mutation in a ts mutant of influenza A virus: Implications for live virus vaccine development. Virology 1977; 83: 356-64.

13. Maassab HF, DeBorde DC, Donabedian AM, Smitka CW. Prospects for influenza type B live attenuated virus. In: Kendal AP. Patriarca PA, eds. Options for the Control of Influenza. New York: Alan R. Liss Inc, $1986 ; 271-86$.

14. Murphy BR, Markoff LJ, Chanock RM et al. Genetic approaches to attenuation of influenza A viruses for man. Phil Trans R Soc Lond 1980; B288: 401-415

15. Heath AW, Addison C, Ali M, Teale D, Potter CW. In vivo and in vitro hamster models in the assessment of virulence of recombinant influenza viruses. Antiviral Res 1983; 3: 241-52.

16. Toms GL, Davies JA, Woodward CG, Sweet C, Smith H. The relation of pyrexia and nasal inflammatory response to virus levels in nasal washings of ferrets infected with influenza viruses of differing virulence. Br J Exp Path 1977; 58: 444-58.

17. Sweet C, Bird RA, Cavanagh D, Toms GL, Collie MH, Smith $H$. The local origin of the febrile response induced in ferrets during respiratory infection with a virulent influenza virus. $\mathrm{Br} J$ Exp Path 1979; 60: 300-8.

18. Coates DM, Sweet C, Quarles JM, Overton HA, Smith H. Severity of fever in influenza: Study on the relation between viral surface antigens, pyrexia, level of nasal virus, and inflammatory response in the ferret. J Gen Virol 1985; 66: 1627-31.

19. Maassab HF, Kendal AP, Abrams GD, Monto AS. Evaluation of a cold-recombinant influenza virus vaccine in ferrets. J Infect Dis 1982; 146: 780 90

20. Mustard JF, Packham MA. The reaction of the blood to injury. In: Movat $\mathrm{HZ}$, ed. Inflammation. Immunity, and Hypersensitivity. Hagerstown: Harper and Row, 1979; 556-664.

21. Tolpin MD, Massicot JG, Mullinix MG, et al. Genetic factors associated with loss of the temperaturesensitive phenotype of the influenza A/Alaska/77-ts-1A2 recombinant during growth in vivo. Virology $1981 ; 112: 505-17$

22. Odagiri T, DeBorde DC, Maassab HF. Cold-adapted recombinants of influenza $A$ viruses In MDCK cells I. Development and characterization of $A / A n n$ Arbor/6/60 $\times A / A l a s k a / 6 / 77$ recombinant viruses. Virology 1982; 119: 82-95.

23. Maassab HF, DeBorde DC. Characterization of an influenza host range mutant. Virology $1983 ; 130$ : 34250.

24. Nakajima K, Sugiura A. Three factor cross of influenza virus. Virology 1977; 81: 486-9.

25. Sugiura A, Kilbourne ED. Genetic studies of influenza viruses II. Plaque formation by influenza viruses in a clone of a variant human heteroploid cell line. Virology $1965 ; 26: 478-88$.

26. Racaniello VR, Palese P. Influenza B virus genome: assignment of viral polypeptides to RNA segments. J Virol 1979; $29: 361-73$

27. Laemmli UK. Cleavage of structural proteins during assembly of the head of bacteriophage T4. Nature 1970; 227: 680-5. 
28. Horsiberger MA. The large $P$ proteins of influenza $A$ viruses are composed of one acidic and two basic polypeptides. Virology 1980; 107: 302-5.

29. Dahlberg AE, Stellwag EJ. Electrophoretic transfer of DNA, RNA and proteins onto diazobenzyloxymethyl paper. In: Wu R, Grossman L, Moldave K, eds. Methods of Enzymology. New York: Academic Press, 1983; 326-33.

30. Briedis DJ, Lamb RA, Choppin PW. Sequence of RNA segment 7 of the influenza $B$ virus genome: partial amino acid homology between the membrane proteins $\left(M_{1}\right)$ of influenza $A$ and $B$ viruses and conservation of a second open reading frame. Virology $1982 ; 116: 581-8$.

31. Briedis DJ, Lamb RA. The influenza $B$ virus genome sequences and structural organization of RNA segment 8 and the mRNAs coding for the $\mathrm{NS}_{1}$ and $\mathrm{NS}_{2}$ proteins. $J$ Virol 1982; 42:186-93.

32. Krystal M, Young JF, Palese P, Wilson IA, Skehel JJ, Wiley DC. Sequential mutations in hemagglutinins of influenza B virus isolates. Definition of antigenic domains. Proc Nat Acad Sci USA 1983; 80: 452731.

33. Shaw MW, Lamb RA, Ericson BW, Briedis DJ, Choppin PW. Complete nucleotide sequence of the neuraminidase gene of influenze B virus. Proc Nat Acad Sci USA 1982; 79: 6817-21

34. Briedis DJ, Tobin $M$. Influenza $B$ virus genome: Complete nucleotide sequence of the influenza B/Lee/40 virus genome RNA segment 5 encoding the nucleoprotein and comparison with the B/Singapore/222/79 nucleoprotein. Virology 1984; 133: 448- 55.

35. DeBorde DC, Naeve CW, Herlocher ML, Maassab HF. Resolution of a common RNA sequencing ambiguity by terminal deoxynucleotidyl transferase. Anal Biochem 1986; 157: 275-82.

36. DeBorde DC, Donabedian AM, Naeve CW, Maassab HF. Biological characterization and sequence analysis of type $B$ cold-reassortant genes in vaccine development. In: Brown F, Chanock RM, Lerner RA, eds. Vaccines 86- New Approaches to Immunization. Cold Spring Harbor: Cold Spring Harbor Laboratory, $1986 ; 253-9$.

37. Mills J, Chanock RM. Temperature-sensitive mutants of influenza virus 1. Behavior in tissue culture and experimental animals. J Infect Dis $1971 ; 123: 145-57$.

38. Appleyard G, Maber HB. Plaque formation by influenza viruses in the presence of trypsin. J Gen Virol 1974; $25: 351-7$.

39. Dougherty RM. Animal virus titration techniques. In: Harris RJC, ed. Techniques in Experimental Virology. London: Academic Press, 1964; 169-223.

40. Centers for Disease Control. The hemagglutinin inhibition test for influenza viruses. Atlanta Public Health Service, U.S. Department of Health, Education, and Welfare, 1975; 25-62. 